\title{
PERLINDUNGAN HUKUM KONSUMEN DEPO AIR MINUM ISI ULANG YANG HAKNYA DILANGGAR DI KOTA SEMARANG
}

\author{
Galuh Puspa Prameswari, Fitika Andraini \\ Fakultas Hukum, Universitas Stikubank (UNISBANK) Semarang \\ Email : glhprmswr@gmail.com, fitika@edu.unisbank.ac.id
}

\begin{abstract}
ABSTRAK
Dalam kebutuhan sehari-hari sebagai manusia tidak bisa terlepas dari sumber daya alam yang dianugerahi oleh Tuhan Yang Maha Esa khusunya adalah air. Mmasyarakat memilih untuk mengkonsumsi air minum yang diproduksi oleh usaha Air Minum Depot (AMD) dikarenakan kebutuhan air yang bersih dan sehat untuk konsumsi. Tetapi ternyata tidak selalu terjamin kesehatannya karena air minum yang diproduksi oleh Air Minum Depot (AMD) isi ulang masih banyak ditemukannya kuman penyebab penyakit (patogen) dan tidak aman untuk dikonsumsi karena tidak memenuhi standar kelayakan.

Permasalahan yang akan dibahas yaitu tentang perlindungan hukum konsumen bagi hak-haknya dilanggar oleh pelaku usaha depot air minum isi ulang di Kota Semarang, dan mekanisme penyelesaian yang dapat ditempuh untuk menyelesaikan berbagai pelanggaran depot air minum isi ulang yang tidak memiliki izin usahanya di Kota Semarang. Metode pendekatan yang digunakan dalam penelitian ini adalah pendekatan yuridis normatif dengan menggunakan data sekunder berupa bahan-bahan kepustakaan, dokumen-dokumen, dan peraturan perundang-undangan lain yang ada kaitannya dengan penelian yang akan dibahas. Dan teknik analisa yang digunakan bersifat deskriptif analitis.

Perlindungan Hukum Bagi Konsumen Depo Air yang Hak-Haknya Dilanggar Oleh Pelaku Usaha Depot Air Minum Isi Ulang di Kota Semarang, diatur dalam Pasal 60 dan Pasal 62 Undang-Undang Perlindungan Konsumen selain itu juga dalam Pasal 28 Peraturan Menteri Kesehatan Republik Indonesia Nomor 736/Menkes/Per/IV/2010 tentang Tata Laksana Pengawasan Kualitas Air Minum sedangkan Mekanisme Penyelesaian yang Dapat Ditempuh Untuk Menyelesaikan Berbagai Pelanggaran Depot Air Minum Isi Ulang yang Tidak Memiliki Izin Usahanya di Kota Semarang diatur dalam Pasal 47 dan Pasal 48 Undang-Undang Perlindungan Konsumen.
\end{abstract}

Kata kunci : Perlindungan Konsumen, Air Minum Depot (AMD), Izin Usaha 


\begin{abstract}
In our daily needs as a human being cannot be separated from the natural resource that is bestowed by God Almighty, especially water. People choose to consume drinking water produced by the Drinking Water Depot (AMD) business because of the need for clean and healthy water for consumption. But it turns out that health is not always guaranteed because the drinking water produced by the drinking water depot (AMD) refills is still found many germs that cause disease (pathogens) and is not safe for consumption because it does not meet the standard of eligibility.

Issues to be discussed are the legal protection of consumers for their rights being violated by business actors in refill drinking water depots in Semarang City, and the settlement mechanisms that can be taken to resolve various violations of refilled drinking water depots that do not have a business license in Semarang City. The approach method used in this research is a normative juridical approach using secondary data in the form of library materials, documents, and other laws and regulations related to the research that will be discussed. And the analysis technique used is descriptive analytical.

Legal Protection for Water Depot Consumers whose Rights are Violated by Business Actors of Refill Drinking Water Depot in Semarang City, are regulated in Article 60 and Article 62 of the Consumer Protection Law as well as in Article 28 of the Regulation of the Minister of Health of the Republic of Indonesia Number 736 / Menkes / Per / IV / 2010 concerning Procedures for Supervision of Drinking Water Quality, while the Settlement Mechanism that Can Be Taken to Resolve Various Violations of Refill Drinking Water Depots that Do not Have Business Permits in Semarang City are regulated in Article 47 and Article 48 of the Consumer Protection Law.
\end{abstract}

\title{
Keywords: Consumer Protection, Drinking Water Depot (AMD), Business License
}

\section{Pendahuluan}

Indonesia adalah Negara yang mempunyai jumlah kepadatan penduduk yang cukup tinggi. Secara rasio, dimana suatu Negara tersebut mempunyai jumlah penduduk yang tinggi maka akan membutuhkan berbagai jenis kebutuhan yang sangat beragam. Jika dilihat dari tingkatannya, kebutuhan konsumen dibagi menjadi tiga antara lain sandang, pangan, dan papan. Karena berbagai macam kebutuhan tersebut maka setiap manusia akan berupaya untuk memenuhi kebutuhannya. Dalam kebutuhan seharihari sebagai manusia tidak bisa terlepas dari sumber daya alam yang dianugerahi oleh Tuhan Yang Maha Esa khusunya adalah air. Selain oksigen, air juga mempunyai peranan yang cukup besar untuk kelangsungan makhluk hidup di bumi ini. Telah kita ketahui bahwa 70\% tubuh manusia terdiri dari air, yang berfungsi sebagai pengatur suhu tubuh, membantu pencernaan, memelihara kesehatan kulit, dan membantu metabolisme tubuh. Oleh karena itu sudah seharusnya kita memperhatikan kualitas air minum yang kita konsumsi. Pada Pasal 8 ayat (1) butir a UndangUndang No. 8 Tahun 1999 
tentang Perlindungan Konsumen menyebutkan bahwa "pelaku usaha dilarang memproduksi dan/atau memperdagangkan barang dan/atau jasa yang tidak memenuhi atau tidak sesuai dengan standar yang dipersyaratkan dan ketentuan peraturan perundangundangan".

Berdasarkan pasal tersebut pelaku usaha harus memenuhi standar yang ditentukan Undang-Undang jika ingin memproduksi atau memperdagangkan barang dan/atau jasanya. Namun pada kenyataanya, para pelaku usaha tidak melaksanakannya, hal ini dapat dilihat dari banyak pelaku usaha yang mengelabuhi konsumen dengan memberikan barang/jasa yang tidak sesuai dengan standard dan tidak disadari oleh para konsumen. Sebagian air minum isi ulang masih banyak ditemukannya kuman penyebab penyakit (patogen) dan tidak aman untuk dikonsumsi karena tidak memenuhi standar kelayakan. Berbeda dengan Air Minum Dalam Kemasan (AMDK), yang sudah teregistrasi dan memiliki standar kelayakan dari Badan Pengawasan Obat dan Makanan (BPOM) pengawasan kualitas air minum isi ulang menjadi tanggung jawab Dinas Kesehatan pada masing-masing daerah.

Air minum yang tidak sesuai dengan standar kelayakan akan membawa dampak yang kurang baik dalam tubuh jika dikonsumsi secara terus menerus dalam jangka pendek maupun jangka panjang. Efek yang ditimbulkan dalam jangka pendek berupa penyakit diare yang ditimbulkan oleh bakteri seperti Escherichia coli (E-Coli) dan colliform. Sedangkan efek jangka panjang yang ditimbulkan karena mengkonsumsi air kotor tidaklah langsung diketahui, dan memerlukan belasan tahun untuk mengetahui penyakit yang ditimbulkan. Penyakit-penyakit yang muncul biasanya disebabkan dari zat-zat kimia yang terkandung dalam air, diantaranya magnesium (Mg) yang menyebabkan penyakit lever/hati, merkuri ( $\mathrm{Hg})$ menyebabkan gangguan terhadap reproduksi dan gangguan syaraf, klorin $(\mathrm{Cl})$ menyebabkan penyakit ginjal dan bila bereaksi dengan bahan organic akan membentuk senyawa trihalometane (THM) yang dapat menyebabkan penyakit separti kanker, dan lain-lain ${ }^{1}$.

Selain itu karena banyak masyarakat yang kurang mengetahui mengenai hak-haknya sebagai konsumen menyebabkan sering kali pelaku usaha memanfaatkan sebagai celah untuk mengelabuhi para konsumen. Padahal hubungan antara konsumen dengan pelaku usaha dapat dikatakan sangat penting karena saling bergantung satu sama lain. Dengan demikian dibutuhkan landasan hukum untuk melindungi konsumen terhadap hak-haknya supaya tidak lagi diabaikan oleh pelaku usaha. Dalam kaitannya dengan perlindungan konsumen terhadap usaha Air Minum Depot (AMD) isi ulang permasalahan mengenai hak-hak konsumen, dan kewajiban pelaku usaha akan dikaji lebih dalam lagi melalui Undang-Undang Perlindungan Konsumen dan peraturan lainnya yang terkait dengan perlindungan konsumen.

\footnotetext{
1 Akbar Satyalam, Skripsi: "PERLINDUNGAN HUKUM TERHADAP KONSUMEN DEPOT AIR MINUM ISI ULANG DI KOTA YOGYAKARTA" (Yogyakarta: UMY, 2017) hal. 3
} 
Dengan adanya banyak depot air minum isi ulang yang tidak memenuhi standar kualitas air yang ada, maka salah satu hak konsumen untuk mendapatkan barang yang layak tidak terpenuhi. Oleh Karena itu perlu dilakukan pengawasan yang lebih ketat lagi terhadap usaha depot air minum isi ulang agar dalam pelaksanaannya dapat memenuhi standar kualitas air minum yang telah ditentukan oleh perundang-undangan yang telah ada. Latar belakang diatas mendorong penulis untuk menyusul skripsi dengan judul "PERLINDUNGAN HUKUM BAGI KONSUMEN YANG HAKNYA DILANGGAR OLEH PELAKU USAHA DEPOT AIR MINUM ISI ULANG DI KOTA SEMARANG".

\section{Perumusan Masalah}

1. Bagaimana perlindungan hukum bagi konsumen yang hak-haknya dilanggar oleh pelaku usaha depot air minum isi ulang di Kota Semarang?

2. Bagaimana mekanisme penyelesaian yang dapat ditempuh untuk menyelesaikan berbagai pelanggaran depot air minum isi ulang yang tidak memiliki izin usahanya di Kota Semarang?

\section{Metode Penelitian}

Metode pendekatan yang digunakan dalam penelitian ini adalah pendekatan yuridis normatif. Tipe penelitian ini dikenal juga dengan tipe kepustakaan yaitu dengan mempelajari dari bukubuku, dokumen-dokumen, dan peraturan perundangundangan lain yang ada kaitannya dengan penelian yang akan dibahas. Penelitian ini dilakukan dengan cara menelaah konsep-konsep, teoti-teori, serta peraturan perundang-undangan yang berhubungan dengan penelitian ini dan dengan menggambarkan peristiwa yang terjadi dalam penerapan perlindungan hukum kepada konsumen depot air minum.

\section{Spesifikasi Penelitian}

Sesuai dengan judul dan permasalahan yang diteliti, maka jenis penelitian yang akan diteliti adalah Deskriptif analitis, yaitu suatu metode yang pengambilan masalahnya memusatkan perhatian kepada masalahmasalah sebagaimana adanya saat penelitian dilaksanakan, dimana kemudian hasil penelitian diolah kembali untuk diambil kesimpulannya. Maka untuk perlindungan hukum bagi konsumen yang haknya dilanggar oleh pelaku usaha depot air minum isi ulang di Kota Semarang penulis menggunakann motode deskriptif analisis karena dirasa cocok untuk mengetahui fenomena yang sedang berlangsung saat ini.

\section{Sumber Data}

Data Sekunder diperoleh melalui penelitian dari sumber-sumber yang telah ada. Data ini digunakan untuk mendukung informasi yang telah diperoleh dari bahan-bahan pustaka, literatur, buku-buku, penelitian terdahulu, dan lain sebagainya.

Data Primer diperoleh melalui wawancara langsung oleh penulis dengan responden. Dalam penelitian ini yang menjadi responden adalah Dinas Kesehatan Kota Semarang dan Lembaga Pembinaan dan Perlindungan Konsumen (LP2K) Semarang.

\section{Metode Pengumpulan Data}

Studi Kepustakaan yang dilakukan dengan cara mengumpulkan bahan-bahan tertulis berupa bukubuku, karya ilmiah 
pada penelitian sebelumnya, dan dokumen-dokumen resmi yang berhubungan dengan masalah yang akan diteliti. Wawancara dalam penelitian ini wawancara dilakukan kepada Dinas Kesehatan Kota Semarang dan Lembaga Pembinaan dan Perlindungan Konsumen (LP2K).

\section{Metode Analisa Data}

Setelah data dari Dinas Kesehatan Kota Semarang dan Lembaga Pembinaan dan Perlindungan Konsumen (LP2K) terkumpul, kemudian teknik yang digunakan untuk menganalisis penelitian ini adalah data analisis kualitatif. Data analisis kualitatif adalah suatu analisis yang diperoleh dari wawancara, studi kepustakaan, maupun observasi yang kemudian peneliti mempelajari, menganalisis data, menafsirkan dan menarik kesimpulan terhadap fenomena yang terjadi di lapangan.

\section{Pembahasan}

Perlindungan Hukum Bagi Konsumen yang HakHaknya Dilanggar Oleh Pelaku Usaha Depot Air Minum Isi Ulang di Kota Semarang

Berdasarkan sistem hukum yang ada pada saat ini, kedudukan konsumen masih lemah dibandingkan dengan kedudukan pelaku usaha, dan pelaku usaha kerap memandang konsumen sebagai pihak yang mudah untuk dipengaruhi untuk mengonsumsi barang atau jasa yang ditawarkan. Berdasarkan hasil wawancara di Dinas Kesehatan bersama Ibu Johana selaku pengurus bidang Kesehatan Lingkungan dan Promosi Kesehatan, masih banyak sekali Depot Air Minum di Kota Semarang yang belum mendapatkan izin usaha. Padahal untuk mendaftarkan izin usaha tidak dipungut biaya apapun. Di tahun 2019 dan 2020 masih minim sekali Depot Air Minum yang mendaftarkan izin usaha ke Dinas Kesehatan Kota Semarang.

Berikut tabel usaha Depot Air Minum yang mendaftarkan izin usaha ke Dinas Kesehatan pada tahun 20192020

\begin{tabular}{|c|c|c|}
\hline \multicolumn{3}{|c|}{2019} \\
\hline $\begin{array}{l}\text { Nama } \\
\text { Depot } \\
\text { Air } \\
\text { Minum }\end{array}$ & Pemilik & Alamat \\
\hline $\begin{array}{l}\text { Tirta } \\
\text { Medika }\end{array}$ & $\begin{array}{l}\text { Nilawati } \\
\text { Kusumanin } \\
\text { gtyas }\end{array}$ & $\begin{array}{l}\text { Jl.Bougenv } \\
\text { ille Raya } \\
\text { No. } 41\end{array}$ \\
\hline $\begin{array}{l}\text { RSUP Dr. } \\
\text { Karyadi }\end{array}$ & $\begin{array}{l}\text { Agus } \\
\text { Suryanto }\end{array}$ & $\begin{array}{l}\text { Jl.Dr. } \\
\text { Sutomo } \\
\text { No. } 16\end{array}$ \\
\hline $\begin{array}{l}\text { Espe } \\
\text { Foods } \\
\text { Pure } \\
\text { Water } \\
\end{array}$ & $\begin{array}{l}\text { Johana } \\
\text { Juniarti }\end{array}$ & $\begin{array}{l}\text { Jl. } \\
\text { S.Parman } \\
\text { No. } 34\end{array}$ \\
\hline $\begin{array}{l}\text { Nama } \\
\text { Depot } \\
\text { Air } \\
\text { Minum }\end{array}$ & $\begin{array}{r}\mathbf{2 0 2 0} \\
\text { Pemilik }\end{array}$ & Alamat \\
\hline $\begin{array}{l}\text { Granan } \\
\text { Tirta }\end{array}$ & Emmy & $\begin{array}{l}\text { Jl. Seroja } \\
\text { Dalam I } \\
\text { No. } 10\end{array}$ \\
\hline $\begin{array}{l}\text { Toko } \\
\text { Suwarli }\end{array}$ & $\begin{array}{l}\text { Surya } \\
\text { Hangesta }\end{array}$ & $\begin{array}{l}\text { Jl. Septa } \\
\text { Marga III } \\
\text { No. } 311\end{array}$ \\
\hline
\end{tabular}

Konsumen yang merasa dirugikan karena hak-haknya telah dilanggar oleh pelaku usaha depot air minum bisa meminta pertanggungjawaban dari pelaku usaha seperti yang terdapat pada ketentuan Undang-Undang Perlindungan Konsumen Pasal 19 sampai Pasal 28. Menurt Pasal 19 ayat 1 dan 2 Tanggung Jawab Pelaku usaha adalah: "Pelaku usaha bertanggung jawab memberikan ganti rugi atas kerusakan, pencemaran, dan atau kerugian konsumen akibat mengkonsumsi barang dan atau jasa yang 
dihasilkan atau diperdagangkan" "Ganti rugi sebagaimana dimaksud pada ayat (1) dapat berupa pengembalian uang atau penggantian barang dan/atau jasa yang sejenis atau setara nilainya, atau perawatan kesehatan dan/atau pemberian santunan yang sesuai dengan ketentuan peraturan perundang-undangan yang berlaku."

Apabila pelaku usaha tidak melakukan pertanggung jawaban seperti yang tercantum dalam pasal 19 undangundang perlindungan konsumen Badan Penyelesaian Sengketa Konsumen (BPSK) dapat memberikan sanksi kepada pelaku usaha, yaitu berupa sanksi administratif dan sanksi pidana. Sesuai dengan Pasal 60 dan Pasal 62 UndangUndang Perlindungan Konsumen Nomor 8 Tahun 1999. Selain sanksi yang diatur dalam UndangUndang Perlindungan Konsumen ada pula sanksi yang diatur dalam Peraturan Menteri Kesehatan Republik Indonesia Nomor 736/Menkes/Per/IV/2010 tentang Tata Laksana Pengawasan Kualitas Air Minum Pasal 28

Mekanisme Penyelesaian yang Dapat Ditempuh Untuk Menyelesaikan Berbagai Pelanggaran Depot Air Minum Isi Ulang yang Tidak Memiliki Izin Usahanya di Kota Semarang

Banyaknya depot air minum yang tidak steril dan tidak terdaftar izin usahanya membuat konsumen mengalami kerugian yang dapat mengancam kesehatannya. Sesuai dalam Pasal 45 dan Pasal 46 Undang-Undang Perlindungan Konsumen, yang menyetakan bahwa setiap konsumen dapat menggugat pelaku usaha jika hal tersebut merugikan bagi konsumen. Menurut Pasal 47 dan Pasal
48 UndangUndang Perlindungan Konsumen penyelesaian sengketa dapat ditempuh melalui dua cara yaitu melalui pengadilan dan di luar pengadilan.

Berdasarkan bunyi dari Pasal 47 Undang-Undang Perlindungan Konsumen adalah "penyelesaian sengketa di luar pengadilan diselenggarakan untuk mencapai kesepakatan mengenai bentuk dan besarnya ganti rugi dan/atau tindakan tertentu untuk menjamin tidak akan terjadi kembali atau tidak akan terulang kembali kerugian yang diderita oleh konsumen".

Sedangkan dalam Pasal 48 Undang-Undang Perlindungan Konsumen menyatakan bahwa "penyelesaian sengketa konsumen melalui pengadilan mengacu pada ketentuan tentang perdilan umum yang berlaku dengan memperhatikan ketentuan dalam Pasal 45". Untuk LP2K, memberikan bantuan dengan cara menyelesaikan sengketa antara konsumen dan pelaku usaha melalui jalur litigasi dan jalur non litigasi. Tetapi dari keterangan yang diperoleh melalui wawancara dengan pihak LP2K yaitu Pak Mufid selaku Ketua Bidang Pengabdian dan Pelayanan Masyarakat, LP2K mengusahakan agar sengketa dapat diselesaikan melalui jalur non litigasi. Namun apabila jalur non litigasi tidak membuahkan hasil, dapat juga dilakukan upaya penyelesaian sengketa melalui jalur litigasi.

Menurut penulis dalam mekanisme tersebut telah mencakup perlindungan bagi konsumen, namun pada kenyataannya masyarakat belum memahami dengan betul Undang-Undang Perlindungan Konsumen. Hal tersebut 
dapat terlihat dari hasil penelitian yang telah penulis teliti, masih banyak konsumen yang tidak melapor soal kecurangan depot. Rata-rata masyarakat masih membiarkan hal tersebut, padahal hal tersebut dapat mengancam kesehatan kosumen itu sendiri.

\section{Kesimpulan}

Dari pembahasan di atas, kesimpulan yang didapat adalah sebagai berikut :

1. Perlindungan Hukum Bagi Konsumen yang Hak-Haknya Dilanggar Oleh Pelaku Usaha Depot Air Minum Isi Ulang di Kota Semarang, menurut Undang-Undang Perlindungan Konsumen apabila ada pelaku usaha yang melanggar hakhak konsumen dapat dikenakan sanksi berupa sanksi administratif dan sanksi pidana. Sesuai dengan pasal $60 \quad$ Undang-Undang Perlindungan Konsumen Nomor 8 Tahun 1999 "sanksi administratif yang diberikan berupa penetapan ganti rugi paling banyak Rp. 200.000.000,00 (dua ratus juta rupiah)".

Sedangkan sanksi pidana yang diberikan menurut Pasal 62 UndangUndang Perlindungan konsumen, Berupa:

1) Pelaku usaha yang melanggar ketentuan sebagaiman dimaksud dalam Pasal 8, Pasal 9, Pasal 10, Pasal 13 ayat (2), Pasal 15, Pasal 17 ayat (1) huruf a, huruf b, huruf, c, huruf e, ayat (2), dan Pasal 18 dipidana dengan pidana penjara paling lama 5 (lima) tahun atau pidana denda paling banyak Rp.
2.000.000.000,00 (dua miliar rupiah);

2) Pelaku usaha yang melanggar ketentuan sebagaimana yang dimaksud dalam Pasal 11, Pasal 12, Pasal 13 ayat (1), Pasal 14, Pasal 16, dan Pasal 17 ayat (1) huruf d dan huruf $f$ dipidana dengan pidana penjara paling lama 2 (dua) tahun atau pidana denda paling banyak $\mathrm{Rp}$. 500.000.000,00 (lima ratus juta rupiah);

3) Terhadap pelanggaran yang mengakibatkan luka berat, sakit berat, cacat tetap atau kematian diberlakukan ketentuan pidana yang berlaku.

Selain sanksi yang diatur dalam UndangUndang Perlindungan Konsumen ada pula sanksi yang diatur dalam Peraturan Menteri Kesehatan Republik Indonesia Nomor 736/Menkes/Per/IV/2010 tentang Tata Laksana Pengawasan Kualitas Air Minum Pasal 28 yaitu:

1. Apabila penyelenggara air minum tidak melaksanakan tindak lanjut sebagaimana dimaksud dalam Pasal 16, maka Pemerintah Daerah Kabupaten/Kota dapat mengambil tindakan administratif.

2. Tindakan administratif sebagiamana dimaksud pada ayat (1) berupa:

a. Peringatan lisan;

b. Peringatan tertulis; dan

c. Pelanggaran distribusi air minum di wilayahnya.

Menurut Peraturan Menteri Kesehatan Republik Indonesia Nomor 736/Menkes/Per/VI/2010 tentang Tata Laksana Pengawasan Kualitas Air Minum bahwa penetapan jumlah dan frekuensi pengambilan sampel air minum 
pada Air Minum Depot (AMD) isi ulang pada parameter Mikrobiologi, Fisika diujikan satu bulan sekali, sedangkan untuk parameter Kimia wajib dan Kimia tambahan diujikan dalam enam bulan sekali.

2. Mekanisme Penyelesaian yang Dapat Ditempuh Untuk Menyelesaikan Berbagai Pelanggaran Depot Air Minum Isi Ulang yang Tidak Memiliki Izin Usahanya di Kota Semarang, Penyelesaian sengketa dapat ditempuh melalui dua cara, yaitu melalui pengadilan dan di luar pengadilan. Dalam Pasal 47 UndangUndang Perlindungan Konsumen "penyelesaian sengketa di luar pengadilan diselenggarakan untuk mencapai kesepakatan mengenai bentuk dan besarnya ganti rugi dan/atau tindakan tertentu untuk menjamin tidak akan terjadi kembali atau tidak akan terulang kembali kerugian yang diderita oleh konsumen".

Sedangkan penyelesaian sengketa melalui pengadilan menurut Pasal 48 Undang-Undang Perlindungan Konsumen menyebutkan bahwa "penyelesaian sengketa konsumen melalui pengadilan mengacu pada ketentuan tentang perdilan umum yang berlaku dengan memperhatikan ketentuan dalam Pasal 45".

Sedangkan LP2K memberikan bantuan untuk menyelesaikan sengketa antara konsumen dan pelaku usaha dengan dua cara yaitu litigasi dan non litigasi.

\section{Saran}

Berdasarkan hasil penelitian, penulis memiliki saran sebagai berikut:

1. Konsumen yang mengkonsumsi air isi ulang, harus lebih kritis dalam memilih depot air isi ulang, dan sadar akan hakhaknya yang harus dipenuhi oleh pelaku usaha.

2. Pelaku usaha seharusnya tidak hanya mementingkan keuntungan bagi usahanya semata, tetapi juga harus memperhatikan kualitas dari air isi ulang yang diproduksinya, apakah sudah memenuhi standar yang berlaku dan aman untuk dikonsumsi apa tidak.

3. Pengawasan terhadap depot air minum seharusnya lebih dioptimalkan. Misalnya kerjasama antara dua instansi yang berwenang dalam mengawasi depot air minum yaitu Dinas Kesehatan untuk mengawasi kualitas air minum yang diproduksi depot air minum dengan melakukan pengawasan rutin yang seharusnya dilakukan 2 (dua) kali dalam setahun dan Dinas Perindustrian dan Perdagangan dalam persyaratan teknisnya. Dan juga melakukan sosialisasi atau penyuluhan tidak hanya kepada pelaku usaha depot air minum tetapi juga kepada konsumen. Dengan anggaran dan tenaga yang terbatas, Dinas Kesehatan Kota Semarang bisa melakukan sosialisasi di media massa dengan disesuaikan dengan anggaran yang dimiliki.

\section{Daftar Pustaka}

$\underline{\text { Literatur }}$

Asyhadie, Zaeni. 2012. Hukum Bisnis. Depok: PT. Raja Grafindo Persada. 
Barkatullah, Abdul Halim. 2010. Hakhak Konsumen. Bandung: Nusa Media.

Barkatullah, Abdul Halim. 2010. Hukum Perlindungan Konsumen "Kajian Teoritis dan Perkembangan Pemikiran. Bandung: Nusa Media. Fajar ND,

Mukti dan Yulianto Achmad. 2015. Dualisme Penelitian Hukum Normatif \& Empiris. Yogyakarta: Pustaka pelajar.

Kristiyanti, Celina Tri Siwi. 2009. Hukum Perlindungan Konsumen. Jakarta:Sinar Grafika.

Miru, Ahmadi dan Sutarman Yodo. 2015. Hukum Perlindungan Konsumen. Jakarta: PT Raja Grafindo Persada.

Miru, Ahmadi. 2011. Hukum Perlindungan Konsumen. Jakarta: PT. Raja Grafindo.

Nasution, Az. 2007. Hukum Perlindungan Konsumen Suatu Pengantar. Jakarta: Diadit Media.

Sutedi, Adrian. 2008. Tanggung Jawab Produk Dalam Perlindungan Konsumen. Bogor: Ghalia Indonesia.

Widjaja, Gunawan dan Ahmad Yani. 2000. Hukum Tentang Perlindungan Konsumen. Jakarta: Gramedia.

\section{Jurnal}

Banun, Syahirah. 2015. "PERLINDUNGAN HUKUM TERHADAP KONSUMEN PRODUK SAUS SAMBAL INDOSARI”. Jakarta: Universitas Islam Negeri Satyalam,

Akbar. 2017. "PERLINDUNGAN HUKUM TERHADAP KONSUMEN DEPOT AIR MINUM ISI ULANG DI KOTA YOGYAKARTA". Yogyakarta: Universitas Muhammadiyah Yogyakarta

\section{Website}

Hulondalo.id, https://hulondalo.id/standar-kemenkesritentang-syarat-air-minum-layakkonsumsi/, diakses pada 1 Juli 2020 liputan6.com, https://www.liputan6.com/health/read/40 07738/bahay a-konsumsi-air-tidakbersih-yang-siap-melandaselamamusim-kemarau, diakses pada 1 Maret 2020.

sipp.menpan.go.id, https://sipp.menpan.go.id/pelayananpubli k/jambi/kabupaten-batanghari/rekomendasisurat-izin-depot-airminum-isi-ulang, diakses pada $20 \mathrm{Mei}$ 2020. airminumisiulang.com, https://www.airminumisiulang.com/page/ 17/Penyeba b-Jentik-Nyamuk-DalamAir-Galon diakses pada 13 Agustus 2020 